Jurnal Kejaora: Jurnal Kesehatan Jasmani dan Olah Raga

ISSN: 2541-5042 (Online)

ISSN: 2503-2976 (Print)

Volume 5 Nomor 1, Edisi April 2020

\title{
PENGARUH PERCAYA DIRI TERHADAP MENURUNNYA TINGKAT KECEMASAN MENGHADAPI PERTANDINGAN TIM BOLABASKET PUTRI UNIPA SURABAYA
}

\author{
Eka Kurnia Darisman', Muhammad Muhyi² \\ 1,2 Prodi Pendidikan Jasmani Universitas PGRI Adi Buana Surabaya \\ Email: ekakurniadarisman68@gmail.com¹, muhyi@unipasby.ac.id 2 \\ DOI: https://doi.org/10.36526/kejaora.v5i1.767
}

\begin{abstract}
ABSTRAK
Tujuan dari penelitian ini adalah untuk memperoleh informasi tentang munculnya pengaruh percaya diri terhadap kecemasan menghadapi pertandingan pada tim bolabasket putri Universitas PGRI Adi Buana Surabaya. Populasi penelitian adalah seluruh atlet tim bolabasket putri Unipa Surabaya dengan responden penelitian sebanyak 15 atlet. Pengumpulan data penelitian menggunakan skala kepercayaan diri $(r=0,322-0,637 ; a=0,875)$, dan skala kecemasan menghadapi pertandingan ( $r$ $=0,329-0,534 ; a=0,805$ ). Teknik analisis data yang digunakan adalah korelasi product moment Pearson. Pengumpulan data dalam penelitian ini menggunakan angket dan dilakukan satu hari sebelum pelaksanaaan pertandingan pada event campus league 2017. Angket yang dibagikan adalah angket untuk mengukur skala percaya diri dan skala kecemasan pemain bolabasket putri sebanyak 15 orang. Setelah angket terisi, kemudian menguji hipotesis dengan menggunakan analisis teknik korelasi product moment. Hasil dari analisis tersebut diperoleh nilai koefisien korelasi $(R)$ sebesar $-0,528 ; p=0,00(p<0,01)$. Dengan hasil tersebut, maka hipotesis penelitian diterima dan menunjukkan bahwa kepercayaan diri dapat menjadi penentu menurunnya tingkat kecemasan menghadapi pertandingan. Kontribusi kepercayaan diri terhadap kecemasan menghadapi pertandingan adalah sebesar $27,9 \%$ yang ditunjukkan oleh nilai R square sebesar 0,279.
\end{abstract}

Kata Kunci: Percaya Diri, Kecemasan, Bolabasket Putri

\section{PENDAHULUAN}

Para ahli psikologi mengungkapkan bahwa percaya diri dan kecemasan adalah beberapa faktor yang ada dalam aspek mental sebagai penentu kemenangan. Untuk mengetahui kondisi mental setiap atlet, seorang atlet harus mengikuti tes psikologi yang membantu dalam pencapaian prestasi tersebut, seperti halnya tes percaya diri, motivasi, kecemasan dan lain-lain yang mempengaruhi pada kondisi psikologis.

Kesiapan aspek psikologis atlet banyak memperoleh perhatian dalam program pembinaan. Hal ini dikarenakan kondisi psikologis atlet menjadi salah satu faktor penentu kemenangan. Kondisi psikologis dapat dibedakan atas dua macam yaitu yang menunjang penampilan dan menghambat atau menggangu penampilan atau prestasi. Aspek psikologis yang menunjang prestasi diantaranya adalah percaya diri, aspirasi yang kuat, kematangan kepribadian. Sedangkan aspek yang dapat mengganggu prestasi diataranya adalah ketegangan, kecemasan, rendahnya tingkat percaya diri, absesi, gangguan emosional, keraguan atau takut. Dalam Said dan Jannah, 2018, aspek mental yang penting untuk dipahami salah satunya adalah kecemasan. Oleh karena itu, sebagai praktisi olahraga, baik itu atlet ataupun pelatih, perlu memahami dan mempelajari bagaimana kecemasan dapat mempengaruhi hasil dari sebuah pertandingan. Terutama ketika kondisi psikologis menurun, perasaan cemas lebih rentan untuk dialami. Sedangkan untuk percaya diri, bisa dkatakan sebagai salah satu aspek psikologis yang penting dan perlu dimiliki oleh orang yang ingin berhasil. Dengan kata lain, percaya diri adalah aspek psikologis yang berupa keyakinan individu mengenal kemampuannya sendiri untuk menyelesaikan tugas dengan baik (Said dan Jannah, 2018).

Dalam pertandingan bolabasket, kecemasan yang muncul sebelum 
Jurnal Kejaora: Jurnal Kesehatan Jasmani dan Olah Raga

ISSN: 2541-5042 (Online)

ISSN: 2503-2976 (Print)

Volume 5 Nomor 1, Edisi April 2020

pertandingan akan mempengaruhi performa atlet di lapangan. Salah satu contoh yang dapat terjadi karena kecemasan adalah pada saat melakukan freethrow selalu gagal, hal ini dimungkinkan karena diri atlet tersebut sudah mempunyai pikiran-pikiran negatif terhadap kemampuan shootingnya, atlet tersebut meragukan kemampuan dirinya, dan juga berpikir bahwa dirinya tidak akan mungkin dapat memenangkan pertandingan.

Atas dasar fenomena dan penjelasanpenjelasan maupun pertimbangan tersebut di atas, maka penelitian ini tentang adanya pengaruh percaya diri terhadap menurunnya tingkat kecemasan menghadapi pertandingan pada tim bolabasket putri Universitas PGRI Adi Buana Surabaya".

\section{METODE}

Jumlah sampel dalam penelitian ini sebanyak 15 orang, yang tergabung dalam tim bolabasket putri Unipa Surabaya. Pengumpulan data dalam penelitian ini menggunakan metode skala psikologi serta penggunaan angket dan dilakukan satu hari sebelum pelaksanaaan pertandingan. Skala psikologi yang digunakan sebagai berikut:

\section{Skala Kecemasan}

Skala ini digunakan untuk mengukur tingkat kecemasan dalam menghadapi pertandingan seorang atlet. Tingkat kecemasan bertanding diungkap melalui gejala-gejala kecemasan yang dialami atlet dalam menghadapi pertandingan. gejalagejala tersebut dikelompokkan ke dalam dua gejala yaitu: gejala fisik (Y1) dan gejala psikis (Y2).

a. Gejala-gejala fisik merupakan gejala gangguan pada sistem kerja fisiologis tubuh dan terjadinya perubahan tingkah laku pada atlet, meliputi: gelisah, sering menggaruk-garuk kepala, sering jalan mondar-mandir, jantung berdebar, sering ingin buang air kecil, berkeringat dingin, gemetar, gangguan pernafasan, gangguan pencernaan, badan terasa lesu, perubahan irama pernapasan dan otot-otot terasa tegang.

b. Gejala-gejala psikis, antara lain: gangguan perhatian dan konsentrasi,

perubahan emosi, menurunnya rasa percaya diri, menurunnya motivasi, mudah putus asa, tegang, gangguan tidur, gugup, gelisah, khawatir, timbul rasa takut.

Skala Kecemasan ini terdiri dari 30 item dengan perbandingan proporsional bobot pada dua gejala dalam skala ini adalah sama. Azwar, 1999 menyatakan bahwa apabila tidak diperoleh alasan untuk menganggap adanya sebagian indikator yang lebih signifikan dari indikator lainnya, maka semua indikator lebih baik diberi bobot yang sama.

\section{Skala Percaya Diri}

Skala ini digunakan untuk mengukur tingkat motivasi berprestasi atlet dalam menghadapi pertandingan. Skala ini mengandung tujuh indikator yang akan diungkap berdasarkan ciri-ciri atlet yang memiliki motivasi berprestasi tinggi. Hal ini sesuai dengan yang dikemukakan oleh Lilik (dalam Adisasmito, 2007). Skala Percaya Diri ini meliputi :

a. Berani mengambil resiko (X1),

b. melakukan evaluasi (X2),

c. Bertanggung jawab dan disiplin (X3),

d. Tekun atau bersemangat $(X 4)$,

e. Inovatif (X5)

Skala Percaya Diri ini terdiri dari 30 item dengan perbandingan proporsional bobot yang sama pada enam Indikator dalam skala ini. Indikator ini merupakan ciri-ciri yang paling mewakili indikator percaya diri.

Skala Kecemasan dan Skala Percaya Diri disusun atas dua jenis pernyataan, yaitu pernyataan favourable dan unfavourable. Penyusunan kedua skala menggunakan skala Likert. Subjek diminta untuk menyatakan sejauhmana pernyataanpernyataan dalam skala sesuai atau tidak sesuai dengan keadaan dirinya. Cara penyekoran skala ini disesuaikan dengan jenis pernyataan. Setiap pernyataan memiliki lima alternatif jawaban yaitu: Sangat Setuju (SS), Setuju (S), Tidak Tahu (TT), Tidak Setuju (TS), Sangat Tidak Setuju (STS). Dalam pemberian nilai jawaban (skor) untuk pernyataan favorabel bergerak dari angka 5 
Jurnal Kejaora: Jurnal Kesehatan Jasmani dan Olah Raga

ISSN: 2541-5042 (Online)

ISSN: 2503-2976 (Print)

Volume 5 Nomor 1, Edisi April 2020

sampai angka 1. Sedangkan dalam memberikan nilai (skor) untuk pernyataan unfavorabel bergerak dari angka 1 sampai angka 5 .

Setelah uji asumsi terpenuhi, langkah selanjutnya adalah melakukan perhitungan untuk menguji hipotesis yang diajukan. Pengujian hipotesis dilakukan dengan teknik korelasi product moment Pearson untuk mengetahui hubungan antara dua variabel.

\section{HASIL DAN PEMBAHASAN}

1. Uji Asumsi Dasar

a. Uji Normalitas

Hasil uji normalitas dengan menggunakan teknik Kolmogorov-Smirnov, dapat diketahui bahwa nilai signifikansi percaya diri sebesar $0,200(p>0,05)$, dan nilai signifikansi kecemasan menghadapi pertandingan sebesar $0,200(p>0,05)$. Nilai signifikansi untuk percaya diri dan kecemasan lebih besar dari 0,05, maka dapat disimpulkan bahwa kedua variabel tersebut telah terdistribusi secara normal.

\section{b. Uji Linearitas}

Dua variabel dikatakan mempunyai hubungan yang linear bila nilai signifikansi (linearity) kurang dari 0,05. Karena nilai signifikansi yang dihasilkan adalah kurang dari 0,05, maka dapat disimpulkan bahwa terdapat hubungan yang linear antara variabel percaya diri dan kecemasan menghadapi pertandingan.

\section{Uji Hipotesis}

Setelah uji asumsi terpenuhi, langkah selanjutnya adalah melakukan perhitungan untuk menguji hipotesis yang diajukan. Pengujian hipotesis dilakukan dengan teknik korelasi product moment Pearson untuk mengetahui hubungan antara dua variabel. Hasil analisis menunjukkan bahwa besarnya koefisien korelasi antara variabel percaya diri dan kecemasan menghadapi pertandingan menghasilkan nilai signifikansi pada linearity sebesar $-0,528$ dengan nilai signifikansi pada percaya diri dengan kecemasan menghadapi pertandingan adalah 0,000 . Oleh karena signifikansi yang dihasilkan adalah kurang dari 0,05 , maka terdapat hubungan yang

signifikan antara percaya diri dan kecemasan menghadapi pertandingan. Atau dengan kata lain, rasa percaya diri yang tinggi dapat membantu meminimalisir tingkat kecemasan sebelum bertanding. Nilai $r$ yang negatif menunjukkan arah hubungan yang bersifat negatif.

Hasil kategorisasi pada skala percaya diri dapat diketahui bahwa subjek secara umum memiliki tingkat yang tinggi dengan rerata empirik 55\%. Berdasarkan data tersebut, maka dapat disimpulkan bahwa subjek penelitian rata-rata memiliki tingkat percaya diri tinggi. Sedangkan pada kecemasan menghadapi pertandingan sebesar $85 \%$,Berdasarkan data tersebut, maka dapat disimpulkan bahwa subjek penelitian rata-rata memiliki tingkat kecemasan menghadapi pertandingan sedang.

Korelasi antara percaya diri terhadap kecemasan menghadapi pertandingan di peroleh dari koefisien korelasi sebesar 0,528 , dengan signifikansi $0,000(p<0,05)$. Ini menunjukkan bahwa terdapat hubungan negatif yang artinya kenaikan skor variabel bebas (percaya diri) secara bersama-sama akan diikuti dengan penurunan skor variabel terikat (kecemasan) dan sebaliknya, penurunan skor variabel bebas (percaya diri) secara bersama-sama akan diikuti dengan kenaikan skor variable terikat (kecemasan).

Korelasi yang negatif dan signifikan antara percaya diri dengan kecemasan menghadapi pertandingan pada tim bolabasket putri Unipa Surabaya menunjukkan bahwa percaya diri mempunyai peranan penting dalam menentukan sebuah prestasi. Pembuktian hipotesis dalam penelitian ini sejalan dengan hasil penelitian Nuraeni (2010) yang menemukan hubungan negatif dan signifikan antara percaya diri dengan kecemasan. Dikemukakan pula oleh Afiatin dan Martaniah (1998) bahwa percaya diri merupakan aspek kepribadian manusia yang berfungsi penting untuk mengaktualisasikan potensi yang dimilikinya, sehingga percaya diri seorang atlet akan sangat berperan dalam pencapaian prestasi pada dirinya. 
Jurnal Kejaora: Jurnal Kesehatan Jasmani dan Olah Raga

ISSN: 2541-5042 (Online)

ISSN: 2503-2976 (Print)

Volume 5 Nomor 1, Edisi April 2020

Berdasarkan hasil analisis determinasi, diperoleh nilai ( $R$ Square) sebesar 0,279 atau $27,9 \%$. Hal ini menunjukkan bahwa presentase sumbangan percaya diri terhadap kecemasan menghadapi pertandingan adalah sebesar $27,9 \%$ dan masih terdapat $72,1 \%$ faktor lain yang menentukan kecemasan menghadapi pertandingan selain variabel percaya diri. Menurut Susilowati, 2008, variabel lain yang mempengaruhi psikologis pada atlet pada saat bertanding selain percaya diri adalah berpikir positif, penetapan sasaran, motivasi, emosi, komunikasi dengan pelatih, konsentrasi, evaluasi diri. Sumbangan efektif percaya diri sangat berperan untuk mengurangi kecemasan menghadapi pertandingan pada tim bolabasket putri Unipa Surabaya. Pada penelitian yang dilakukan oleh Hartanti, dkk., 2004 juga menyatakan bahwa percaya diri menempati urutan aspek psikologis atlet yang lebih tinggi dibandingkan dengan kemandirian dalam pencapaian prestasi atlet.

Percaya diri pada tim bolabasket putri Unipa Surabaya secara umum tergolong tinggi. Hal tersebut berdasarkan hasil kategorisasi yang memperlihatkan bahwa $55 \%$ responden memiliki skor percaya diri tinggi dan $45 \%$ lainnya memiliki skor percaya diri sedang, dengan mean sebesar 9,088. Berdasarkan data tersebut, maka dapat diketahui bahwa tim bolabasket putri Unipa Surabaya memiliki percaya diri yang tinggi. Adanya percaya diri yang tinggi akan mampu mengurangi kecemasan menghadapi pertandingan pada tim bolabasket putri Unipa Surabaya.

Kecemasan menghadapi pertandingan pada tim bolabasket putri Unipa Surabaya secara umum tergolong sedang. Hal tersebut berdasarkan hasil kategorisasi yang memperlihatkan bahwa $85 \%$ responden memiliki skor kecemasan menghadapi pertandingan sedang, $12,5 \%$ lainnya memiliki skor kecemasan menghadapi pertandingan rendah, dan 2,5\% memiliki skor kecemasan menghadapi pertandingan tinggi, dengan mean sebesar 7,664. Berdasarkan data tersebut, maka dapat diketahui bahwa tim bolabasket putri Unipa Surabaya memiliki tingkat kecemasan menghadapi pertandingan sedang. Hal ini dimungkinkan karena pada saat akan mengikuti suatu pertandingan, tim bolabasket putri Unipa Surabaya mempersiapkan atletnya dengan berlatih secara rutin.

\section{KESIMPULAN}

1. Pada penelitian ini terdapat hubungan yang negatif antara percaya diri dengan kecemasan menghadapi pertandingan pada tim bolabasket putri Unipa Surabaya. Nilai hubungan antara percaya diri dengan kecemasan menghadapi pertandingan pada tim bolabasket putri Unipa Surabaya yang dihitung dengan koefisien korelasi adalah $-0,528$, dengan nilai Sig. $0,000 \quad(p<0,05)$. Dengan demikian semakin tinggi percaya diri tim bolabasket putri Unipa Surabaya dalam menghadapi pertandingan maka akan menurunkan kecemasan menghadapi pertandingan pada tim bolabasket putri Unipa Surabaya.

2. Besarnya sumbangan efektif percaya diri terhadap kecemasan menghadapi pertandingan adalah sebesar $27,9 \%$.. Hal ini berarti masih terdapat $72,1 \%$ faktor lain yang menentukan kecemasan menghadapi pertandingan selain variabel percaya diri.

3. Hasil analisis deskriptif menunjukkan bahwa rata-rata responden penelitian memiliki percaya diri tinggi sebanyak $55 \%$ dengan rerata empirik 9,088; dan kecemasan menghadapi pertandingan sedang sebanyak $85 \%$ dengan rerata empirik 7,664 .

\section{SARAN}

1. Kepada Atlet di tim bolabasket putri Unipa Surabaya, dapat meningkatkan percaya diri dengan lebih rajin mengikuti latihan baik secara terjadwal maupun mandiri sehingga akan lebih sering bertemu dan berinteraksi dengan banyak orang/tim lainnya. Tim bolabasket putri Unipa Surabaya juga hendaknya lebih sering mengikuti kejuaraan baik di tingkat regional maupun nasional, sehingga lebih sering berinteraksi dengan lawan dalam persaingan yang sehat dan lebih kompetitif sehingga hal tersebut akan 
Jurnal Kejaora: Jurnal Kesehatan Jasmani dan Olah Raga

ISSN: 2541-5042 (Online)

ISSN: 2503-2976 (Print)

Volume 5 Nomor 1, Edisi April 2020

meningkatkan percaya dirinya, terlebih bila sering menjuarai pertandingan. Ketika percaya diri telah berfungsi secara penuh maka akan mengurangi kecemasan dalam menghadapi suatu pertandingan.

2. Kepada pelatih tim bolabasket putri Unipa Surabaya, faktor psikologis atau faktor mental berperan dalam pencapaian prestasi atlet sehingga perlu adanya kerjasama antara pembina dengan lembaga psikologi untuk meningkatkan kemampuan psikologis atau mental pada atlet karate yang akan menimbulkan keseimbangan pada diri atlet. Pelatih memberikan pemahaman yang mendalam tentang cabang olahraga yang dilatihkan, dari keterampilan dasar hingga taktik dan strategi lanjutan. Teknik dan peraturan permainan selalu berkembang, dan pelatih diharapkan mengikuti dan menguasai perkembangan tersebut agar atlet dapat mempunyai gambaran tentang pencapaian prestasi yang harus didapatkannya.

\section{DAFTAR PUSTAKA}

Adisasmito, L.S. (2007). Mental Juara Modal Atlet Berprestasi. Jakarta: RajaGrafindo Perasada.

Arifin, Z. (2009). Metodologi Penelitian Pendidikan. Surabaya: Lentera Cendika.

Arikunto, S. (2006). Prosedur Penelitian Suatu Pendekatan Praktek. Edisi Adisasmito, Lilik Sudarwati. 2007. Mental Juara Modal Atlet Berprestasi. Jakarta: RajaGrafindo Perasada.

Azwar, S. (1999). Penyusunan Skala Psikologi. Yogyakarta: Pustaka Pelajar.

Azwar, S. (1999). Penyusunan Skala Psikologi. Yogyakarta: Pustaka Revisi VI. Jakarta: Rineka Cipta.

Ghozali, I. (2001). Aplikasi Analisis Multivariate dengan Progran SPSS. Semarang : Badan Penerbit Universitas Diponegoro.

Gunarsa, S.D., Satiadarma, M.P., Soekasah, M.H. (1995). Psikologi Olahraga. Jakarta: PT BPK Gunung Mulia Jakarta.
Hadi, S. (2000). STATISTIK, Yogyakarta : Andi Offiset

Husdarta, H.J.S. (2010). Psikologi Olahraga. Bandung: Penerbit Alfabeta Bandung.

Kosasih, E. (1994). Pendidikan Jasmani SMA Kelas 2. Jakarta: Erlangga.

Muhajir. (2007). Pendidikan Jasmani Olahraga dan Kesehatan. Bandung: Erlangga Bandung.

Purwanto, N. (2004). Psikologi Pendidikan. Bandung: PT Remaja Rosda Kary

Riduwan. (2003). Dasar-dasar Statistik, Bandung: Alfabeta Bandung.

Sadiman. (1996). Interaksi dan Motivasi Belajar Mengajar. Jakarta: CV Rajawali Press.

Said, H dan Jannah, Ml. (2018). Penentu Kemenangan "Problematika dan Solusi Mental Dalam Olahraga". Surabaya. Unesa University Press.

Setiadarma, M.P. (2000). Dasar-Dasar Psikologi Olahraga. Jakarta: Pustaka Sinar Harapan.

Suryana, K.D. (2004). Taekwondo. Teknik Dasar, Pomse, dan Peraturan pertandingan, Gramedia Pustaka Utama. Jakarta.

Sugiyono. (2008). Metode Penelitian Kuantitatif Kualitatif dan $R$ \& $D$. Bandung: Alfabeta Bandung.

Triyuliana. (2007). Pengolahan Data Statistik dengan SPSS 15.0, Yogyakarta: Penerbit Andi dan Wahana Komputer Yogyakarta. 